\title{
BARBERRY BUSHES
}

AND WHEAT

ANDREW McFARLAND DAVIS 
<smiles>C1CC1</smiles> 


\section{BARBERRY BUSHES A ND WHEAT}

BY

ANDREW McFARLAND DAVIS

REPRINTED FROM

THE PUBLICATIONS

OF

The Colonial Dociety of $\mathfrak{A}$ assachusettg

VOL. XI

C A M B R I D GE

JOHN WILSON AND SON

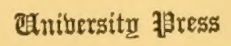

1907 


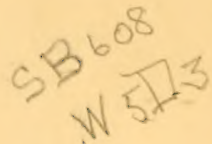

Gift

Autho:

(Porron)

22 N 0 ?

$\therefore \vdots$ 


\section{BARBERRY BUSHES AND WHEAT - A SUPPLEMENT TO A CHAPTER IN "THE OLD FARMER AND HIS ALMANACK."}

In offering for the consideration of this Society the following comments on the subject of Barberry Bushes and Wheat, which will serve perhaps as a supplement to one of the chapters in Professor Kittredge's recently published work, The Old Farmer and his Almanack, I may perhaps be pardoned if I preface them with a few words concerning almanacs in general, their functions and their evolution. If these introductory remarks shall seem to be unnecessary, it will be recognized, at least, that they will help us to appreciate the character of the work upon which Mr. Kittredge entered when he undertook to analyze the pages of the Farmer's Almanac.

An almanac is defined by the Encyclopædia Britannica as -

a book or table, published from year to year, containing a calendar of the days, weeks and months of the year, a register of ecclesiastical festivals and saints' days, and a record of various astronomical phenomena, particularly the rising and setting of the sun and moon, the times of high water at particular ports, etc. In addition to these contents, which may be regarded as essential to the almanac, it generally presents additional information, which is more or less extensive and varied according to the many different special objects contemplated in works of this kind.

The author of the article from which the above is quoted also says that the almanac proper is often secondary to a variety of extraneous matter included in the publication, and he refers to two of these annuals "as works of general statistical reference . . . of very great value."

The Century Dictionary says: "Many annual publications called almanacs are largely extended by the insertion of historical, political, statistical and other current information as supplemental to the calendar."

Many statistical works of this class have become absolutely essential for one who would keep up with the times. The digests 
of current political events contained in the almanacs published annually by the leading New York papers, for example, are indispensable for the politician who deals with national affairs. In a similar way there are in Europe compilations known as almanacs having international reputations, to which a student may turn with confidence for information as to imports and exports, national debts, military and naval equipments and expenditures, and the current events of political importance which have occurred during the year next preceding their issue. One of these, having a special feature of its own, is described in Scribner's Monthly for January, 1907. "The Almanach De Gotha," says the writer, -

is to Europe what Burke and Debrett and the other Peerages are to the British Isles, and it is also the lineal ancestor and model of such topical encyclopædias as our "Whittaker", our "Hazell" and our "Statesman's Year-Book." A political and social history of the world for the last one hundred and fifty years could be written from its back numbers if these were readily accessible to students. But they are not. The Almanach De Gotha began to appear in 1763, but the purchasers did not file it for reference. The earliest numbers in the British Museum are those for 1774 and 1783 , and a complete set can only be found in the editorial offices in Friederich's Allee in the little Thuringian capital whence the 141st issue was lately published.

The Nation for January 3, 1907, says, "The Almanach De Gotha for 1907 (its 144th year) comes to us as usual and takes its place among books reserved for reference." 1

The belief in the influence of the heavenly bodies upon the condition and affairs of men, early led to the introduction in almanacs not only of prognostications as to the weather but also of prophecies of events. The popularity based on these appeals to the super-

1 The almanacs printed by the Cambridge Press in the early days of the Colony have attracted the attention of bibliographers, and their value in the eyes of collectors has been greatly enhanced by their rarity. One among them, in which the calculations were made by a future President of Harvard College, is thus alluded to by Cotton Mather, in his life of Urian Oakes in the Magnalia:

Being here a lad of small, as he never was of great stature, he published a little parcel of astronomical calculations with this apposite verse in the title page :

Parvum parva decent, sed inest sua Gratia parvis.

The "parcel of astronomical calculations" was the Almanac for 1650. 
stitions of the purchasing public soon caused these publications to assume the form of annuals. In England a government monopoly of the right "to sell almanaes and prognostications" remained in force for nearly one hundred and seventy-five years from the date of the grant.

The original letters patent were issued under James I, October 29,1603 . They were surrendered and renewed in the 13 th year of the reign, 1615, the original letters being recited in the renewal. "Full power, privilege and authority" were given, "to print or cause to be printed, all manner of almanacks and prognostications whatever in the English tongue, and all manner of books, tending to the same purpose, being allowed by the Archbishop of Canterbury and Bishop of London." The letters contained a "prohibition to all other printers \&c. not to buy, sell, or utter any other than should be printed by the said Company." The monopoly originally granted to two individuals came into the hands of the Stationers' Company and the profits were for a time shared with the Universities of Oxford and Cambridge. ${ }^{1}$ It was attacked from time to time in the courts and was finally overthrown in 1775 , in a suit against one Thomas Carnan. ${ }^{2}$ There were two points raised in this case - one that the monopoly applied only to almanacs approved by the Archbishop of Canterbury and the Bishop of London - the other that it was not good anyway. The decision was sweeping against the monopoly. How it could have prevented the publication of almanacs not approved by those clerical authorities during this period, may perhaps be gathered from the definition of an almanac given in the suit of the Company of Stationers against Seymour in $1654 .^{3}$

1 In 1781 an annual allowance was made to each of these universities by the government, " in lieu of the Money heretofore paid to the said Universities by the Company of Stationers of the City of London, for the Privilege of printing Almanacks." The tenth section of the Act in which this was accomplished recites that the privilege of printing and vending almanacs had been granted to the universities and by them demised to the Company of Stationers, for which they had received one thousand pounds and upwards annually. This privilege had by a late decision at law been found to be "a common right, over which the Crown had no Controul, and consequently the Universities no Power to demise the same to any Person or Body of Men"' (21 George III, Ch. 56).

22 W. Blackstone, p. 1003 et seq.

8 Trinity Term of the Court of Common Pleas, 29 Car. II and reported 1 Mod. p. 256. 
Seymour was sued in an action of debt, for printing Gadbury's Almanack without leave of the Company. The Court opens its decision sustaining the monopoly in the following language:

There is no difference in any material part betwixt this almanack and that which is put in THE RUBRICK of the common-prayer. Now the almanack that is before the common-prayer proceeds from a public constitution; it was first settled by the Nicene Council; is established by the canons of the church; and is under the government of the Archbishop of Canterbury; so that almanacks may be accounted prerogative copies.

The Court then goes on to say, "There is no particular author of an almanack," and deals with the special matter included in the publication as follows: "Those additions of prognostications and other things that are common to almanacks do not alter the case."

Fortunately for posterity this case was overruled in 1775, and Mr. Carnan was permitted to publish "A Diary for the Year of our Lord 1774," without responsibility to the Stationers' Company for his profits. The dictum propounded by the Court in 1654, that "There is no particular author to an almanack," has also been set aside by authorities competent for the purpose. Allibone practically settled this question when he enrolled the name of Robert B. Thomas in his Dictionary of Authors, and Oscar Fay Adams endorsed the decision by admitting the name among those which he thought worthy of record in his similar work, limited, however, to those who claimed to be American authors. Drake, when he gave the name a resting place in his Dictionary of American Biography, to all intents and purposes made the same decision, and from his work the question was passed on to the editors of Appletons' Cyclopædia of American Biography, where the approval by James Grant Wilson and John Fiske of the insertion of Thomas's name secured the public endorsement of two other authorities to this repudiation of the doctrine propounded in the old decision.

There is still another dictum in the Seymour case which has been quoted, viz.: "Those additions of prognostications and other things that are common to almanacks do not alter the case," i. e., to go back to the decision, these additions "made no difference in any material part betwixt" Gadbury's "almanack and that which is put in the Rubrick of the Common-Prayer." We may assume 
that Gadbury's had many of the features which distinguish the Farmer's Almanac and hence can cite The Old Farmer and his Almanack as evidence that the Court was also in error in this statement. Thus the whole fabric of the decision is toppled over, and the name of Thomas, which in spite of this ancient decision had already secured recognition as an author when The Old Farmer and his Almanack appeared, has through this recent publication secured a fresh hold upon fame. Existing sets of the Almanac might be destroyed ; dictionaries and encyclopædias might disappear, and still Professor Kittredge's work might be relied upon to vindicate the reputation of the Almanac and rescue the name of its author from oblivion.

The title-page of the volume containing the chapter on Barberry Bushes and Wheat which has occasioned this paper, contained the following description of the contents of the book: "Observations on Life and Manners in New England a Hundred Years Ago, suggested by reading the earlier numbers of Mr. Robert B. Thomas's Farmer's Almanack Together with Extracts, Curious, Instructive and Entertaining, as well as a Variety of Miscellaneous Matter."

Notwithstanding the fact already shown that certain annual publications under the name of almanacs have acquired reputation as historical authorities upon special points, it cannot be denied that it required some courage on the part of Professor Kittredge to attempt an analysis of the "new, useful and entertaining matter" with which Thomas was accustomed to promise his readers that they would be rewarded if they should peruse the pages of his Almanac. Nor does the fact that Thomas has - as disclosed above - secured recognition through this work as an author, diminish to any great extent the tax upon the courage that was required for a careful and deliberate investigation of a publication like the Farmer's Almanac, which not only did not purport to be historical in character, but which still clung to the feature of prognostications and to sundry other of the things alluded to by the Court in 1654 as "common to almanacks." Prognostications of this sort and the absurdity of some of the material with which almanacs from the earliest times were garnished has, in times past, offered a ready theme for satirists like Rabelais and Swift, and indeed continues to do so to this day. Nevertheless, mixed 
in with the information about the planets, one might expect to find, in addition to absurd medical prescriptions, notices of saints' days and predictions of weather and occurrences, occasional references to historical events. From much of this miscellaneous mixture of worthless stuff, the intelligence of Thomas protected whoever should analyze the pages of his Almanac, and the promise on his title-page that it would be found to contain "as great a variety as are to be found in any other Almanac of NEW, USEFUL and ENTERTAINING MATTER" consequently had some value. Yet it will readily be admitted that there was still a great demand left upon the discretion of one who should be required to analyze a complete set of this work in search for historical matter.

Facing page 81 of The Old Farmer and his Almanack there is a reproduction of a page from the Almanac itself where we may see in facsimile the entries for the month of October, 1800. Under the heading "Courts, Aspects, Holidays, Weather, \&c. \&c.," predictions are given that on the first there will be "Cool Breezes;" on the fifth it will "Storm;" on the eighth, ninth, and tenth it will be "Pleasant for the Season;" and so on through the month. Information as to tides, sun-rise, eclipses, and church festivals is varied with what was of equal importance to a large part of the community, the dates and places of assemblage of the Supreme Judicial Court and the Court of Common Pleas. The historical anniversaries alluded to are: "16th, Q. of Fr. behead 1793;" "17th, Burgoyne sur. 1777;" " 30 th, Pres. Adams born 1735." Under the heading "Farmer's Calendar" there is a good deal of sound advice to the farmer as to what may be done to advantage at this season of the year and what also ought not to be done.

A glance at this facsimile page will reveal the size of the task which was imposed upon one who would run through the great number of pages of this character, necessitated by the search for topics alluded to therein which might bear upon life and manners in New England a hundred years ago, even though reliance was placed upon prefatory matter, rather than upon the pages of the Calendar. It is with keen appreciation of the thorough manner in which this work was performed by the author of The Old Farmer and his Almanack, that I venture to take up the subject introduced under the title "Barberries and Wheat" on page 327, in the hopes that what I can add thereto may prove to be of interest. 
Mr. Kittredge quotes from the Almanac a letter dated at Malden, August 26, 1799, written by one P. Sprague, who speaks of the barberry bush as " the most pernicious bush that ever I knew grow upon the face of the earth, multiplying exceedingly fast though great pains are taken by many of our people to clear their lands of them, but to no purpose. Some cut them down, some burn them on where they were cut; others attempt to pull them up with their oxen, but they soon sprout again four to one, and it is said by many, that there is no way to clean the land of them." The writer then goes on to preseribe the following method of getting rid of them:

\section{An effectual Method to Destroy Barberry Bushes.}

Let a man take a small chain with short links, and lay it on the ground round a bunch of bushes, then lay one of the hooks across the chain and draw it as snug as he can with his hands about the bush close to the ground, then put on a sufficient team to bring it up by the roots at once. If this be done in the months of October or November, it will never fail to exterminate them.

Sprague's letter is introduced by the author with the preliminary statement that "The barberry already had a bad reputation. It infested the land and was a great nuisance to farmers on account of its tenacity of life," the italies being mine.

Having thus transcribed to his pages Mr. Sprague's effective method for destroying the bushes, Professor Kittredge continues as follows: "Our correspondent, it will be noted, has nothing to say of the blasting powers of the barberry, but we have a very circumstantial account of them from about the same time, in President Dwight's narrative of his journey to Berwick, Maine, in 1796." Extensive quotations are then given from this narrative. President Dwight dwells at length upon the pest that the barberry bush had proved to be to farmers in Eastern Massachusetts. He says " neat farmers" are able to keep them down in the open fields, but cannot eradicate them along the division walls. He expresses the belief that it would be impossible to get rid of them without tearing down the division walls, i. e. the walls which separate the fields from each other as well as from the highways. "The bush," he says, "is, in New England, generally believed to blast both wheat and rye." This he attributes to the blossoms which for 
a long time emit a pungent eflluvium "believed to be so acrimonious as to injure essentially both these kinds of grain." He then enumerates instances of observation which justify this belief. A single barberry bush grew upon the southern side of a wheat field in Long Island. Southerly winds prevailed when it was in bloom. The effluvium and the dead blossoms were borne over a small breadth in the field to a considerable distance. Wherever this took place the wheat was blasted. In Worcester County, Massachusetts, he heard of two similiar cases. In the first of these, which he describes at length, there also was a single barberry bush at the south end of the field, and there also "the grain was blasted throughout the whole field, in a narrow tract commencing at the bush and proceeding directly in the course and to the extent in which the blossoms were diffused by the wind." The second of these cases was of substantially the same character. It occurred in the same township as the one just described and was disclosed to him by the same authority.

Dr. Dwight's conclusions are given in the following words: "As no part of the grain was blasted in either of these cases, except that which lay in a narrow tract leeward of the barberry bushes; these facts appear to be decisive and to establish the correctness of the common opinion. Should the conclusion be admitted; we cammot wonder, that wheat and rye should be blasted wherever these bushes abound."

Having got on track of these well authenticated and specific instances of the evil effect of permitting barberry bushes to grow in proximity to fields of grain, we may be sure that they furnished the Doctor a topic of conversation and at last he found one person ready to bring the new charge against the barberry bush that it was an enemy to esculent roots. He did not, however, accept this as proven, but in winding up his indictment of the pernicious bush, he says, with reservation, "If there be no error in the account, it indicates that the barberry bush has an unfavorable influence on other vegetable productions beside wheat and rye." 1

Professor Kittredge then quotes from Lieutenant John Harriot who speaks of the difficulty of growing wheat in 1794, on the seacoast in New England, which is attributed by some to saline

1 Dwight, Travels in New England and New York, i. 381-383. Cf. i. 376. 
vapors, by others to the vicinity of barberry bushes. " Harriot's own opinion was that the true causes were poor soil and bad management.

The chapter on "Barberry Bushes and Wheat" which is under our consideration closes with the statement that "The innocent barberry bush gradually lost its bad eminence in the farmer's mind." In thus declaring innocent the culprit indicted by President Dwight with such vigor and force, our author was evidently affected by the close proximity to the end of his chapter, in the arrangement of his material, of the doubts of Harriot and of certain other doubts of later date, to which also he refers. It is to the question whether the specifie charges of President Dwight were not entitled to preference that I now address myself, and the authorities which I shall cite belong to the New England of a hundred years ago and upward as well as to the modern scientific world.

Let us turn first to the statutes of the Province. We shall find, if we examine the legislation of the General Court in December, 1754 , that this very subject was there taken up and that a temporary Act to remain in force for nine and one-half years was then passed, the purpose of which was to secure the extirpation of the barberry bush in Massachusetts. It will also be seen that the difficulty alluded to by President Dwight with regard to the division walls was recognized at that time and provision was made for the destruction of the bushes where they grew in walls or fences. This legislation is introduced by a preamble which distinctly asserts that "the blasting of wheat and other English grain is often occasioned by barberry bushes." The tenacity of life of the pernicious bush, so strongly set forth in tho Sprague letter, was evidently recognized by those who drew up this statute, but the sole cause for this legislation was, if we may accept the allegations of the preamble, because of the office of the barberry bush in blasting grain. Unfortunately we have no record of the journey through Massachusetts of any Dr. Dwight in 1750, and must depend exclusively on the general assertions of this preamble and the character of the legislation itself for our knowledge of the observed facts on which the statute was based. The observations

1 Struggle through Life, London, 1807, ii. 32-33. 
recorded by Dr. Dwight must have occurred about thirty years after the expiration of the temporary act referred to. It may be that for a time the farmers got the upper hand of the barberry bush. At any rate, it will be noted that all knorvledge of the legislation or of the experience which led up to it would seem to have been forgotten when Dr. Dwight and his interlocutors exchanged views upon the character of the barberry bush. ${ }^{1}$

For an appreciation of the completeness with which the ground was covered by those who drew up this statute it is necessary to reproduce the Act itself in full. It may, however, be useful before doing so to say that the law was evidently based upon the belief that the people of the Province demanded its passage. The power, therefore, to carry out its provisions was given to the people. Primarily the owner or occupant of the land was required to remove all barberry bushes; if he failed to do so, methods were prescribed through which any person might enter on the land and remove the bushes and collect from the owner for services in doing the work. The occupant of land also had his right of collection from the orrner for work of this sort. The only penalties imposed by the act were fines on towns in case the surveyors of highways neglected to destroy the bushes in the highways of their districts.

The following is the language of the Statute:

Preamble. THEREAS it has been found, by experience, that the blasting of wheat and other English grain, is often occasioned by barberry-bushes, to the great loss and damage of the inhabitants of this Province, -

Be it therefore enacted by the Governour, Council and House of Representatives,

Barberry-bushes [Sect. 1.] That whoever, whether community or private to be extirpated
on or before Jume, 1760 . or their land within any of the towns in this province be or they shall cause the same to be extirpated or destroyed on or before the tenth day of June, Anno Domini one thousand seven hundred and sixty.

1 This will apply equally as well to the earlier and later Connecticut legislaion ou the same subject which is quoted hereafter (pp. 89-91, 93). 


\section{Be it further enacted,}

[Sect. 2.] That if there shall be any barberry bushes Libertyafter standing or growing, in any land within this province, after persion to cut the said tenth day of June, it shall be lawful, by virtue of them dawn, prothis act, for any person whomsoever to enter the lands wherein such barberry-bashes are (first giving three months' notice of his intention so to do, to the owner or occupant thereof) and to cut them down, or pull them up by the roots, and then to present a fair account of his labour and charge therein to the owner or occupant of the said land; and if such owner or occupant shall neglect or refuse by the space Provision in case of two months next after the presenting of said account, pauts ueglect, to make to such person reasonable payment as aforesaid, \&c. then the person who cut down or pulled up such bushes, may bring his action agaiust such owner or occupant, owners or occupants, before any justice of the peace, if under forty shillings; or otherwise, before the inferiour court of common pleas, in the county where such bushes grew; who, upon prcof of the cutting down or pulling up of such bushes, by the person who brings the action, or such as were employed by him, shall and is hereby, respectively, empowered to enter up judgment for him to recover double the value of the reasonable expence and labour in such service and award execution accordingly.

Be it further enacted,

[Sec. 3.] That if the lands on which such bushes grow Actions may be are common and undivided lands, that then an action may cases of the like be brought, as aforesaid, against any one of the proprietors, in such manner as the laws of this province provide in such cases where proprietors may be sued.

\section{Be it further enacted,}

[Sec. 4.] That the surveyors of the highways, whether Surveyors of publick or private, be and hereby are empowered and re- powered to ex. quired, ex officio, to destroy and extirpate all such barberry bushes stiuding bushes as are or shall be in the highways in their respective wards or districts; and if any such shall remain after the aforesaid tenth day of June, Anno Domini one thousand seven hundred and sixty, that then the town or district in which such bushes are, shall pay a fine of two shillings Penalty, in case. 
for every bush standing or growing on such highway, to be recovered by bill, plaint, information, or the presentment of a grand jury, and to be paid, one half to the informer and the other half to the treasurer of the county in which such bushes grew, for the use of the county.

Be it further enacted,

Provision if such bushes grow in stone wall, or fence.

Owner or proprietor to pay for pulling up or stroying said bushes.

Limitation.
[Sec. 5.] That if any barberry bushes stand or grow in any stone wall, or other fence, either fronting the highway, or dividing between one proprietor and another, that then an action may be brought, as aforesaid, against the owner of said fence, or the person occupying the land to which such land belongs; and if the fence in which such bushes grow is a divisional fence between the lands of one person or community and another, and such fence hath not been divided, by which means the particular share of each person or community is not known, then action may be brought, as aforesaid, against either of the owners or occupants of said land.

\section{Be it further enacted,}

[Sect. 6.] That where the occupant of any land shall eradicate and destroy any barberry bushes growing therein, or in any of the fences belonging to the same (which such occupant is hereby authorized to do, and every action to be brought against him for so doing shall be already barred) or shall be obliged, pursuant to this act, to pay for pulling them up or cutting them down, that then the owner or proprietor of such land shall pay the said occupant the full value of his labour and cost in destroying them himself, or what he is obliged to pay to others as aforesaid; and if the said owner or owners shall refuse so to do, then it shall be lawful for said occupant or occupants to withhold so much of the rents or income of said land as shall be sufficient to pay or reimburse his cost or charge arising as aforesaid.

[Sect. 7.] This act to continue and be in force until the tenth day of June one thousand seven hundred and sixtyfour. [Passed December 26, 1754 ; published, January 13, 1755. $]^{1}$

1 Massachusetts Province Laws, 1754-55, Ch. 20, iii. 797, 798. 
It will be seen that five years and a half were given within which owners of land were to extirpate all the barberry bushes in the Province, and that provision was made for procuring the work to be done in the case of common or undivided lands, as well as in cases of doubtful responsibility such as that of bushes growing in division walls. To secure the accomplishment of this work, reliance was placed upon the authority given to the general public to perform it in ease of neglect by the owner. The Act was of a temporary nature. It expired by limitation in 1764 . Much of the legislation of that day was temporary, and if there seemed to be occasion for renewal, the operation of such statutes was from time to time extended. This particular statute was not extended. Whether we may infer from this its success or its failure, is a matter purely for conjecture. In view, however, of the fact that modern botanists have established beyond doubt a connection between the barberry bush and the rust which infects wheat, it would seem probable that this wholesale attack upon the barberry bushes of Massachusetts probably had such a beneficial effect that when the time of the expiration of the Act came round it was not thought necessary to stimulate farmers by public legislation to protect their wheat fields in the future.

This subject cannot properly be closed without mention being made of what the function of the barberry bush is in propagating rust on growing wheat. In order to do this we must necessarily trespass upon a field of scientific research foreign to the objects of this Society, but fortunately for our special purpose we have at our command material which will in the main be intelligible, even if we are not ourselves sufficiently skilled to comprehend technical details.

First, let us quote from a note to this chapter in the Province Laws, written by our associate Mr. Abner C. Goodell. He says:

It will be seen in the following communication to Silliman's Journal, by the distinguished botanist, Dr. Asa Gray of Cambridge, that the sagacity of the promoters of this measure is fully vindicated by the later researches of European cryptogamists:

The effect of barberry-bushes in rusting wheat, after having been long accounted a groundless popular superstition, is at length understood and admitted by the cryptogamists. The botanists used to rebut the farmers by the statement that the rust in the grain-fields and the prevalent fungus of the 
barberry belonged to very different genera, and that therefore the one could not give origin to the other. But De Bary in Germany and CEersted in Denmark, following up similar inquiries by Tulasne in France, have concluded that Uredo, Puccinia and $A$ cidium are to be regarded, not as so many genera, but as three successive forms of fructification of the same fungus, or, in some sort, an alternation of generations. De Bary ascertained that the spores of Puccinia graminis do not germinate when sprinkled on the leaves and stalks of the cereal grains, which this rust infests, while they will germinate on the leaves of the barberry, and there give rise to the Ecidium berberidis; and the spores of this are equally inert upon the barberry, but will grow, in their turn, upon wheat, and then reproduce first the Uredo, or yellow rust, and later the Puccinia graminis or dark rust. Another species of Puccinia equally produces Ecidium upon buckthorn; another alternates between the cereal grains and certain boragineous weeds. These results have been practically tested, in the large way, last summer (1869) in France. Long hedges of barberry planted along the Paris and Lyons railway in a commune in the Côte d'Or, were complained of by the adjacent cultivators and were cut away at certain places by way of experiment; and an investigation by the railroad company, whose interests were adverse to such a decision, left no doubt of the injurious effects of the barberry on the contiguous wheat fields. - American Journal of Science and the Arts, vol. 49, 1870, p. 406 (No. CXLVII., 2d series).

The French account referred to is in "Bulletin de la Société Botanique de France," tom. 16, $p p$. 331-333. ${ }^{1}$

The foregoing may perhaps be considered adequate to establish the fact that our ancestors were on the right track; that it was not the mere "tenacity of life" of the barberry bush which disturbed them, but that its presence was an actual menace to the wheat. If, however, we require more evidence we may turn to that encyclopedic dictionary, The Century, where we shall find the following definition for Puccinia, which may be considered as fully corroborating the charge of complicity on the part of the barberry bush in propagating rust.

Puccinia-A genus of parasitic fungi of the class Uredinece; the rusts. Plants of this genus exhibit the phenomenon of heterœcism, that is, they pass through different stages of their life-history upon different host plants. $P$. graminis, one of the commonest and most destructive species, may be taken as a type. It appears in the spring on the leaves of the Berberis vulgaris, constituting what is known as barberry rust, or barberry cluster cups. This is the æcidial stage, and

1 Massachusetts Province Laws, iii. 835. 
receired the name of AEcidium Berberidis before the heterocism was suspected. Later in the season the uredo stage makes its appearance on the leaves and stems of the cultivated oats, wheat, etc., appearing as pale yellowish or whitish spots on the leaves. Soon the tissues are ruptured and the long lines of orange red, uredo spores are exposed, now constituting the red rust of oats, etc. By the rapid germination of the uredo spores the disease is quickly spread, and may involve the entire plant. In the fall, just before cold weather, the black teleuto-spores are produced. This is known as the black rust, and is designed to carry the fungus over the winter, when it again begins its life-cycle on the barberry. About 450 species of Puccinia are known, not a few of which are serious pests to the agriculturist or borticulturist.

Our somewhat desultory discussion has taken us into the domain of almanacs; we have quoted largely from English law reports and from a book written about a set of almanacs; we have invaded the field of Provincial legislation; and finally we have been stranded upon that abstruse modern science, cryptogamic botany.

The discussion of purely botanical questions is foreign to the purposes of this Society, yet I cammot refrain from communicating the substance of a letter to me from Professor Charles E. Bessey of the University of Nebraska. After speaking of the rust and its methods of propagation, Professor Bessey says:

It was noticed, however, long ago, that there was wheat rust in abundance where there were no barberry bushes, and in some places there were barberry bushes that were not affected with rust to any great extent. The explanation of this is that for some reason or other, the rust is not wholly dependent upon its barberry phase of existence. On the plains and prairies of the west there are no barberry bushes excepting a few that are planted in the gardens and on the grounds around houses, and yet this species of rust, Puccinia graminis is very abundant. Some years ago it was found that the phase of rust which occurs on the wheat plant is able to live through the winter. Infection may take place in the late autumn, and the rust persists through the winter, so that there is no need of infection of the wheat in the spring of the year from the barberry bushes. I should say that the autumn infection of the wheat is from the preceding wheat crop.

We have here, apparently, an interesting case of a clange of habitat of a parasite, whereas it formerly (and normally) lived first on the barberry, where it gained sufficient strength to form large spores able to 
penetrate the wheat, and then on the wheat to develop its second-stage. Now, apparently, under farorable conditions offered by the wide cultiration of winter wheat, this rust parasite is able to pass from wheat crop to wheat crop directly.

Thus we have the testimony of a recognized authority on such suljects whose residence in Nebraska has permitted personal observation. This evidence is of such a nature that we can no longer deny the possibility of an "innocent" barberry bush. Yet this does not release the pernicious bush from the condemnation which it received at the hands of President Dwight, nor ought it to lessen our admiration for the observations of our ancestors made in New England under circumstances when the widespread cultivation of winter wheat did not present the favorable conditions for the propagation of rust upon the wheat plant itself which now exist upon the plains and prairies of the West. On the contrary, we must admit the sagacity which could connect cause and effect under conditions which, according to Dr. Gray, led scientific men to account this " a groundless superstition" which they sought to rebut by declaring the rust on the wheat to be incapable of origin from the fungus on the barberry bush. The farmers proved to be right and the botanists of that day wrong.

Two things are impressed upon us as a result of this review of an interesting but comparatively unimportant matter. The first of these, the unerring sagacity with which observers traced out the source of the contamination of the wheat fields, has already been dwelt upon. The state of botanical science at that time did not permit that the mysterious method of propagation should be then revealed, but it will be admitted that a compulsory application of the legislation which sought to cure the evil by removing the source of propagation could only have produced beneficial results. Apparently, in after days doubts were thrown by scientific men upon the justice of the recorded observations, and then, under the influence of these doubts, came forgetfulness of the lesson which had been so thoroughly learned. In a similar way the experiences through which the same people passed, during the period when they were dependent upon bills of public credit for a medium of trade, furnished a complete object lesson as to the evils of a redundant irredeemable paper currency, a lesson which was freely accepted by 
the best intellects of the Province. Yet this too was neglected by their posterity when the printing-press proved a more convenient method than borrowing for covering an emergent need. Whatever may be the feelings of the student of our Provincial history at finding this tendency to forget well certified experienees, he will at least be grateful for their evidences of intelligent observation and receptive mentality on the part of our forefathers.

The foregoing, relative to barberry bushes and wheat, has not touched upon the legislation in the other New England Colonies on the same subject. To fill out this gap in the discussion I add hereto certain references to the Colonial Records of Connecticut and Rhode Island, which have been furnished me by Mr. Albert Matthews, and it seems to me that the statutes referred to are entitled to be given in full. The oldest legislation upon the subject took place in Connecticut in May, 1726, when the following act was passed:

\section{An Act concerning Barberry Bushes.}

Whereas the abounding of barberry bushes is thought to be very hurtful, it being by plentiful experience found that, where they are in large quantities, they do occasion, or at least increase, the blast on all sorts of English grain,

Be it therefore enacted by the Governour, Council and Representatives, in General Court Assembled, and by the authority of the same, That the inhabitants of the several towns within this Colony, may and they are hereby fully impowered at their annual town meetings, to determine and agree upon the utter destroying of the said bushes within their respective townships, and the time and manner how. And if any of the inhabitants of such town or towns so agreeing shall oppose the cutting down said bushes within their fields and enclosures, and forbid the other inhabitants coming thereinto for that end, they shall incur the penalty of twenty shillings, to be paid into the treasury of the town wherein they dwell. And if any such person shall thenceforward continue to oppose the cutting said bushes as aforesaid, they shall also incur the penalty of ten shillings per month until they shall declare to the Selectmen their free consent for their entering into such enclosures and destroying the said bushes therein growing. Said penalties to be recovered by distraint on the goods and chattels of the person or persons so offending. 
Provided nevertheless, That if any person or persons have any of said bushes, the which they make use of or depend upon for a fence, such person or persons shall not incur either of the aforesaid penalties till after just satisfaction to them male by the town, as they and the selectmen can agree; or as by two or three indifferent men, chosen by said parties or appointed by the civil authority, shall judge reasonable. ${ }^{1}$

It will be seen that the Massachusetts statute was anticipated in Connecticut by upwards of a quarter of a century. The method of procedure in Connecticut was peculiar, the whole matter being referred to the several towns, thus making it almost certain that there would be no concert of action throughout the Colony. Moreover, the hands of the opponents of the bill are to be seen in the proviso, which threw upon the towns the necessity of first settling with farmers who might claim that the ofiending bushes were made use of or depended upon as fences, before they could enforce any of the penalties of the Act.

The caution with which the preamble of the Act is drawn is worthy of notice. The presence of barberry bushes in great quantity was "thought" to be very hurtful; plentiful experience having shown that large quantities of the bushes occasion "or at least increase " the blast of all sorts on English grain. Of course those who drew up this preamble were ignorant that the fungus required a host-plant and that the different varieties of æcidium could propagate upon different plants, but they had discovered the essential fact that the barberry bush "at least increased " the blast on grain. Its extirpation might not entirely remove the rust from the wheat, but they felt sure it would reduce it.

The power thus lodged in the towns remained there unaltered for fifty-three years. There is no indication that the subject was under discussion in Connecticut during these years, but the fact that there was during this period legislation against barberry bushes in Massachusetts and in Rhode Island suggests the possibility that the action of these Colonies may have been brought to the notice of the government. At any rate in January, 1779, a new Act was passed, authorizing in a general way the destruction of barberry bushes, at certain times of the year, but still leaving the enforcement of the Act to the discretion of town-officers. This Act follows.)

1 Colonial Records of Connecticut, vii. 10. 
An Act in Addition to and Alteration of the Law of this State entituled An Act concerning Barberry Bushes.

Be it enacted by the Governour, Council and Representatives, in General Court assembled, and by the authority of the same, That any person or persons whatsoever, with the adrice and consent of the civil authority and selectmen, or the major part of them, of the town where any barberry bushes are or shall be growing, may in the months of March, April, October or November, enter into and upon any lauds whereon shall be growing any barberry bushes and dig up and destroy such bushes without being liable to any action, suit or demand therefor; any law, usage or custom to the contrary notwitustanding. ${ }^{1}$

(The first legislation in Rhode Island was not until ten years after that in Massachusetts and is to be found in the Records of the Colony for the year 1766. The Act, which applies only to the town of Middletown, was passed in August of that year. It reads as follows:

An Act for destroying barberry bushes in Middletown.

Whereas experience showeth, that barberry bushes have a very great tendency to blast English grain,

Be it therefore enacted by this General Assembly, and by the anthority of the same it is enacted, That where any person in the town of Middletown, hath any barberry bushes growing in his or her field, or enclosure, and shall be applied to by any free holders in said town, to destroy them, and the person so applied to, shall refuse or neglect for the space of one month, to to [sic] cut up and destroy them, that then, and in such case, it shall, and may be, lawful for the person so applying, to make application to one of his Majesty's justices of the peace, who is hereby empowered to grant forth his warrant to impress labourers to cut and destroy all the barberry bushes there growing (for the destroying of which, applications hath been mde [sic] as aforesaid,) at the cost and charge of the complainant or complainants and not at the expense of the owner of the land, committing as little waste, and doing as little damage to the owner of the land, as the case will admit of.

\section{God save the King. ${ }^{2}$}

If the title of this Act had been changed to "An Act to protect barberry-bushes in Middletown," it would have definol its appar-

1 State Records of Connecticut, ii. 176.

2 Rhode Island Colonial Records, vi. 509. 
ent purpose about as well. The method of procedure laid down for the freeholder of the town who wished to compel his neighbor to eradicate the barberry bushes in his fields was so complicated, elaborate and expensive, and so many dangers lurked under the phrase, "doing as little damage to the owner of the land as the case will admit of," that it practically insured the peaceful life of barberry bushes in Middletown.

In the seventh volume of the Records of Rhode Island, an Act for the destruction of barberry bushes throughout the Colony is referred to. ${ }^{1}$ Although the text of this Act is not given in the published Records, it is to be found in the Session Laws for the year 1772. )

The following is the language of the Act:

Act for destroy- AN ACT for destroying Barberry-Bushes throughout ing Barberry Bushes. this Colony.

Preamble.

WHEREAS it is found by Experience that BarberryBushes are very destructive to English Grain:

Persons neglecting to cut or destroy their Barberry-Bushes to loe lined $\& 1000$

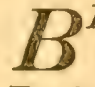

$E$ it therefore Enacted by this General Assembly, and, by the Authority thereof, It is Enacted, That if any Freeholder in this Colony shall apply to any Person having Barberry Bushes growing in his Field or Inclosure to destroy them, and the Owner of the Land shall neglect or refuse to cut them annually, or otherwise destroy them, he shall pay as a Fine, the Sum of 'Ten Pounds Lawful Money, One Half to and for the Use of the Town in which the Barberry Bushes grow, and the other Half to the Informer, to be recovered by Information before the Court of GeneralSessions of the Peace, where the Land lies.

Barberry-Bushes in Commons or Highways to be destroyed by the Town.
$A N D$ be it further Enacted by the Authority aforesaid, That if any Barberry-Bushes shall be found in the Commons or Highways in any Town in the Colony, and any Freeholder of any Town therein, shall make Application to the Town-Treasurer of such 'Town to destroy them; and such Town-Treasurer shall refuse or neglect so to do, for the Space of One Year, That then, and in such Case, such Free-

1 Rhode Island Colonial Records, vii. 51. 
holder may make Application, to any One of His Majesty's Justices of the Peace for said Town, who is hereby empowered and required to grant his Warrant to procure Labourers to cut up and destroy the said Barberry-Bushes; the Expence whereof shall be paid out of the Town-Treasury of such Town. ${ }^{1}$

This is a decided improvement upon the earlier Rhode Island statute, if its purpose was, as its title indicates, to secure the destruction of barberry bushes, and its presence upon the statute books of the Colony doubtless furnished a weapon for those who were disposed to make war upon this mischief-making bush.

A glance at the chronology of this legislation is instructive as well as interesting. The Colony of Connecticut began the war against the barberry bush in 1726 . The subject was taken up in the Province of Massachusetts Bay in 1756. Ten years later, Rhode Island was awakened to the situation and joined, in a half-hearted way, in the fight. After an interval of six years this last Colony, in 1772, took the subject up again and this time passed an Act which, if not all that the enemies of the barberry bush might wish, was at any rate much more pronounced in its efforts to secure the destruction of the bush than the earlier statute. Then comes the second attack of Connecticut, now a State, in 1779. This statute was perhaps capable of being made more effective than the law of 1726 , but was still hampered by the deference to the town officers which was the characteristic feature of the first legislation on the subject, and which is perhaps to be explained by the system of representation which has prevailed there from the days of the Charter to the present time. That the subject should have attracted so much attention in New England as is indicated by the foregoing review of the legislation, and then should have been so completely forgotten that modern cryptogamists were obliged to start at the bottom in their scientific study of this fungus, is very remarkable.

A quotation has already been made from Dr. Gray, giving the results of modern scientific study of the fungus which makes its home upon the barberry bush. A few words may, perhaps, be appropriately added as to the knowledge and the possibility of

1 Rhode Island Laws, August, 1772, p. 46. 
knowledge of this legislation on the part of European and American botanists. I am indebted to Dr. William G. Farlow, of the Department of Cryptogamic Botany in Harvard University, for the following references which, as far as they go, cover this ground. He tells me that as long ago as 1788 , a German traveller in the Middle and Southern States published an account of his experiences and observations, in which he referred to this legislation. The author was obviously a disbeliever in the charges against the barberry bush, but he gives a brief account of the law derived from hearsay during his travels in the section of the country indicated above, and not from actual inspection of the printed statute. ${ }^{1}$ It is not certain to which of the laws he referred, but it is interesting to discover that this legislation was the subject of discussion at this time, so far from the locality where the pest provoked these laws. $^{2}$

The Massachusetts statute was referred to in various botanical journals towards the close of the last century, ${ }^{3}$ and in 1882 Professor Farlow forwarded to Charles B. Plowright of King's Lynn, England, the full text of the law. This was published by him as a supplement to a communication to the Lynn News of December 23,1882 , and was reprinted on a separate sheet under the heading "Wheat Mildew."

The cultivation of wheat in this country has persistently moved away from the coast as our population has increased with such regularity, that after a little study of the statistics of emigration, one who knew the population of the country at a given date could easily predict where the contemporaneous wheat fields would be found. The question of the protection of wheat from fungi is no longer of interest in New England, but perhaps the same spirit of observation which inspired the legislation which we have been discussing, applied to the great wheat fields in the Middle West may be helpful to our farmers to-day.

1 Johann David Schöpf, Reise durch einige der mittlern und südlichen vereinigten nordamerikanischen Straten nach Ost-Florida und den BahamaInseln unternommen in den Jahren 1783 und 1784. Erlangen, 1788.

${ }^{2}$ The possibility that Arthur Young may have seen this naturally suggests itself. In that event the presumption that it was instrumental in leading up to the series of observations chronicled by Young and quoted by Mr. Kittredge (p. 96, below) makes this reference doubly interesting.

\& See Botanical Gazette, May, 1884, ix. 83. 

LIBRARY OF CONGRESS |||||||||||||||||||||||||||||||||||

00028159614 